Article

\title{
Uncovering Stakeholder Participation in Payment for Hydrological Services (PHS) Program Decision Making in Mexico and Colombia
}

\author{
Andres M. Urcuqui-Bustamante ${ }^{1}$, Theresa L. Selfa ${ }^{1, *\left(\mathbb{D}, \text { Paul Hirsch }^{1} \text { and Catherine M. Ashcraft }\right.}{ }^{2}$ (D) \\ 1 Department of Environmental Studies, SUNY College of Environmental Science and Forestry, \\ New York, NY 13210, USA; aurcuqui@esf.edu (A.M.U.-B.); pahirsch@esf.edu (P.H.) \\ 2 Department of Natural Resources and the Environment, College of Life Sciences and Agriculture, \\ University of New Hampshire, Durham, NH 03824, USA; catherine.ashcraft@unh.edu \\ * Correspondence: tselfa@esf.edu
}

Citation: Urcuqui-Bustamante, A.M.; Selfa, T.L.; Hirsch, P.; Ashcraft, C.M. Uncovering Stakeholder Participation in Payment for Hydrological Services (PHS) Program Decision Making in Mexico and Colombia. Sustainability 2021, 13, 8562. https://doi.org/ $10.3390 /$ su13158562

Academic Editor: Leslie A. Duram

Received: 9 July 2021

Accepted: 26 July 2021

Published: 31 July 2021

Publisher's Note: MDPI stays neutral with regard to jurisdictional claims in published maps and institutional affiliations.

Copyright: (c) 2021 by the authors. Licensee MDPI, Basel, Switzerland. This article is an open access article distributed under the terms and conditions of the Creative Commons Attribution (CC BY) license (https:// creativecommons.org/licenses/by/ $4.0 /)$.

\begin{abstract}
Payment for ecosystem services (PES) is a market-based policy approach intended to foster land use practices, such as forest conservation or restoration, that protect and improve the benefits from healthy, functioning ecosystems. While PES programs are used globally, they are an especially prominent environmental policy tool in Latin America, where the vast majority are payment for hydrological services (PHS) programs, which incentivize the conservation and restoration of ecosystems associated with water production and clean water for clearly defined water users. As a market mechanism, PHS approaches involve a transactional relationship between upstream and downstream water users who are connected by a shared watershed. While existing literature has highlighted the important role of non-state actors in natural resource management and program effectiveness, few studies have explored the role of stakeholder participation in the context of PHS programs. Building on the collaborative learning approach and the Trinity of Voice framework, we sought to understand how and to what extent PHS program stakeholders are engaged in PHS design, implementation, and evaluation. In this paper we explored (1) the modes of stakeholder engagement in PHS programs that program administrators use, and (2) the degree to which different modes of stakeholder participation allow PHS stakeholders to have decision power with which to influence PHS policy design and expected outcomes. To better understand the role of stakeholder participation, and the different ways participation occurs, we used a comparative multiple-case study analysis of three PHS program administration types (government, non-profit, and a mixed public-private organization) in Mexico and Colombia that have incorporated stakeholder engagement to achieve ecological and social goals. Our analysis draws on institutional interviews to investigate the modes of stakeholder engagement and understand the degree of decision space that is shared with other PHS stakeholders. Across all cases, we found that the trust between key actors and institutions is an essential but underappreciated aspect of successful collaboration within PHS initiatives. We conclude with recommendations for ways in which program administrators and governmental agencies can better understand and facilitate the development of trust in PHS design and implementation, and natural resources management more broadly.
\end{abstract}

Keywords: ecosystem services; public participation; environmental governance; stakeholder engagement; policy issues; watershed agreements; payment for hydrological services (PHS)

\section{Introduction}

Payment for hydrological services (PHS) is a market-based strategy used to incentivize the conservation of forests and ecosystems by providing financial incentives to hydrological service providers, especially to low-income landowners [1-7]. Yet, recent studies on the impacts of PHS programs on land use and land cover and socioeconomic outcomes in 
central Veracruz, Mexico, have shown that two PHS programs produced limited socioeconomic impacts and low forest cover [8-11]. Additionally, critical social science scholars have argued that addressing the drivers of deforestation and forest degradation requires innovative multidisciplinary methods to understand the complexity, controversy, and uncertainty of coupled human and natural systems [12-14].

In order to deal with the complexity of coupled human and natural systems, researchers in sustainability science and environmental conflict analysis have suggested the use of the collaborative learning approach integrated into participatory research tools, such as participatory modeling, community mapping, public forums, scenario building, and roleplay simulation to face situations in which multiple parties with different identities, values, and goals dispute environmental issues or ecological attributes that are characterized by technical complexity and scientific uncertainty [13-17].

Grounded in ideals of democratic deliberation, collaborative learning is a framework and set of techniques that seeks to foster critical thinking, open communication, common understanding, and interactive negotiation between diverse stakeholders [17-19]. To foster collaborative processes, scholars encourage interdependent parties to work together in problem solving and joint decision making [12,18-21]. Genuine participation of diverse stakeholders is key in collaborative processes [18,21,22].

Participation is increasingly seen as a mechanism to improve public policies and programs by incorporating local needs and perspectives on environmental issues [23-25]. Scholars and advocates of stakeholder participation in policy design and decision making have argued that public participation may increase the effectiveness of government policies by helping agencies make better decisions, increasing project "buy-in" from different parties, building capabilities among citizens and citizen groups to frame problems, engage in deliberations, and impact outcomes, strengthening ties within communities and between the government and non-state actors, as well as raising awareness of complex environmental problems [22,26-29].

Scholars in public participation have used different ideas of public participation [30], Ref. [31] to analyze the role of non-state actors in environmental governance, inform environmental public policies through knowledge exchange, foster collaborative problemsolving of environmental threats, and encourage marginalized stakeholders to have a voice in the decision making process $[17,22,28,32,33]$. Yet, the evaluation of participatory processes in environmental decision making has been limited.

Senecah (2004) has proposed the framework of the Trinity of Voice (TOV) to evaluate the effectiveness of environmental participatory processes by understanding how decision power is shared with the public to affect the outcomes of public policies [34]. TOV is based on the idea that people should have access to, standing in, and the possibility to influence decision making [13,22]. Access refers to opportunities to be informed and able to communicate one's own interests, concerns, choices, and opinions. Civic standing refers to opportunities for debate, dialogue, deliberation, and knowledge exchange where contributions are valued and respected. Influence refers to opportunities for affecting the outcomes of participatory processes and environmental decision making, which also depends on the decision space shared with the public.

Scholars who have applied the TOV framework to analyze participation in environmental decision making have posited that the public needs more effective mechanisms to influence decision making by strengthening their capacities and technical knowledge, building trust between state and non-state actors, and exercising their citizenship [13,18]. Giving people a voice in environmental decision making processes could contribute to trust building, as trust plays a critical role in allowing different parties to join efforts to solve common problems [35].

Trust is a key factor in fostering collaborative processes [17,34]. Research in environmental collaborative governance highlights that trust "forms the core of any effective participation process, and the integrity of community capacity is dependent on building, preserving, and enhancing trust and voice through ensuring that all stakeholders have the 
possibility of access, standing, and influence" [17] (p. 2). The TOV framework helps to understand how trust is built and plays an important role in participatory processes.

Building on the collaborative learning approach and Senecah's TOV framework, we sought to understand how and to what extent PHS program stakeholders are engaged in PHS design, implementation, and evaluation. In this paper, we explored (1) the modes of stakeholder engagement in PHS program decision making that program administrators use $[25,31,36,37]$, and (2) the degree to which different modes of stakeholder participation allow PHS stakeholders to have decision power to influence PHS policy design and expected outcomes $[13,17,21,34]$. We used a multiple-case study approach to analyze the concept and degree of stakeholder participation that PHS program administrators use to engage diverse PHS program stakeholders in decision making.

This paper uses results from institutional interviews from three case studies in Mexico and Colombia to highlight responses from participants about participation in program design, implementation, monitoring, and the role of diverse program stakeholders in decision making. Understanding the role of stakeholders in PHS program decision making and how diverse modes of stakeholder engagement impact collaborative processes within PHS initiatives contributes to the discussion of ideal methods of public participation to produce social and environmental outcomes [31]. The paper focuses on issues of trust, power, and public engagement to inform PHS program administrators and policy makers about the needs for successful collaboration within PHS initiatives. The paper begins by describing our case studies and the methods used for conducting institutional and community member interviews. Next, we present results and discuss the modes of stakeholder participation that PHS program administrators and other actors use to engage the public in PHS program decision making.

\section{The Case: Stakeholder Participation in Payment for Hydrological Services (PHS) Program Decision Making}

PHS is a type of economic tool for conservation that incentivizes forest conservation and sustainable agricultural practices in water production-related zones by offsetting the opportunity costs of foregoing destructive land uses such as intensive agriculture, cattle ranching, and logging $[6,10,38]$. PHS consists of "the use of payment (or compensation) mechanisms to create economic incentives for protecting forests and their hydrologic services that are equal to or greater than the opportunity costs foregone by limiting land use options" [38] (p. 25).

Several international organizations, environmental non-profits, and governments have promoted the use of PHS programs worldwide with the assumption that they produce social benefits such as additional income to small landowners, poverty alleviation, and social capital, alongside environmental benefits [7,39-42]. A review of the literature in PHS found that there are at least 387 PHS programs currently functioning worldwide [43]. PHS is a mainstream environmental policy grounded in ideas of neoliberal conservation that seeks to address the economic drivers of deforestation and forest degradation through economic means [44-47].

PHS has received criticisms from critical scholars due to its narrow economic approach, top-down structure and lack of involvement of PHS program stakeholders in decision making [39,48-52]. Critical scholars and advocates of alternatives to market-based conservation often call attention to the ways global environmental policies expand neoliberal programs and the commodification of nature $[46,47]$. Based on criticisms of PHS as a neoliberal tool for conservation, yet acknowledging the role of local actors in resisting international environmental policies, recent publications have called for an investigation into how local actors (PHS stakeholders) shape neoliberal programs to meet local needs [53-55]. Through case study research, social scientists have highlighted some of the institutional, cultural, and economic patterns that influence the adaptation of PHS policies to local contexts [50,54,56-59].

We respond to this call by using a multiple-case study approach to better understand how, by whom, and to what extent, program stakeholders are engaged in PHS decision 
making and have been able to influence its outcomes. We focused our analysis on the mechanisms of PHS administration and methods of stakeholder participation that PHS program administrators, governmental agencies, non-profits, and other actors have used to engage the public in the decision making, implementation, and evaluation of the PHS program. Our comparative analysis explores the multivariate causal patterns [60,61] across the case studies that influence program decision making and have helped to adopt and/or shape international policies in a way that meets local contexts [53]. Ultimately, we sought to understand the role of PHS stakeholders in environmental decision making by highlighting the similarities and differences between the case studies.

\subsection{Local Matching Funds Payment for Hydrological Services Programs in Central Veracruz, Mexico}

Facing persistent urban problems associated with water scarcity and low water quality, the Mexican government launched a federal PHS program named Programa de Pago por Servicios Ambientales Hidrológicos in 2002 that sought to incentivize forest conservation in areas of high deforestation risk [62-65]. Mexico's federal PHS program was initially managed by the National Forestry Commission, Comisión Nacional Forestal, or CONAFOR, with funding from Mexico's Federal Rights Law, the Mexican Forest Fund, and additional funding from the Federal Congress $[62,64]$.

After subsequent revisions due to criticism by local scholars, the federal government launched the Local Matching Funds PHS (LMF-PHS) schemes, Mecanismos Locales de Pago por Servicios Ambientales a través de Fondos Concurrentes, in 2008 to increase local commitment to the program and secure its long-term sustainability by conditioning CONAFOR's support to the financial contribution of local stakeholders, such as municipalities, water utilities, and companies [41,52,54]. In LMF-PHS programs, a local organization administers the program, discusses PHS program eligibility with CONAFOR, signs agreements with landowners, monitors landowners' compliance with contract conditions, and communicates results to the local and federal government and the broad public $[41,52,62]$.

Mexico's 20-year experience with federal and local PHS schemes has been recognized as a model in Latin America of successful PHS implementation [65] and has received great attention from biophysical and social science scholars [8,9,11,66-69]. According to Pfaff et al. (2019), by 2016 the vast majority of the 157 market-based schemes for conservation in Mexico were PHS programs. LMF-PHS programs have been used to tackle land use changes in places such as central Veracruz, Mexico, an area with one of the highest rates of deforestation in the country $[9,38]$.

The Central Veracruz area is of high conservation priority given that it hosts several endangered tropical ecosystems, such as the humid montane forest and tropical oak forest, and has great plant endemism [70]. A recent study in Mexico shows that the conversion of land cover in the tropical moist forest of Veracruz is driven mainly by pasture expansion [71]. In a 21-year study period (1993-2014) of land cover change in Central Veracruz, GómezDíaz et al. (2018) found that the area covered by remnant vegetation was reduced overall by $57 \%$, though there was a slight recovery between 2000 and 2014 . Deforestation and degradation of the forest in Central Veracruz contribute to historic environmental problems in the area, such as low water quality, water shortages, and lowland flooding [38].

Our Veracruz case studies focus on two separate PHS programs in the cities of Coatepec (85,000 population) and Xalapa (425,000 population), located in La Antigua River watershed. Coatepec's PHS program is one of the first experiences in PHS implementation in Mexico [64,68]. The program started in 2002 following the PHS federal model, but it was revised and adapted to the LMF-PHS model after 2008 [64,65]. The program is administered by a local trust fund called Fideicomiso Coatepecano del Agua para los Servicios Ambientales Hidrológicos or FIDECOAGUA and has strong participation from the City of Coatepec [11].

The program has a governing body where key governmental organizations and big corporations can influence decision-making [68]. The program receives funding from CONAFOR, the City of Coatepec, and the Municipal Water Commission (Comisión Munic- 
ipal de Agua Potable y Saneamiento de Coatepec or CMAS Coatepec) [68]. A small water fee is charged to water users through the water bill and the cost is stratified according to the nature of the users (i.e., household or industry) [68]. The program budget is formally part of the city budget.

FIDECOAGUA payments for forest conservation covers around 1548 ha in the Gavilanes sub-watershed [68]. Most of the program beneficiaries are private landowners, yet there is participation of some ejidatarios, community members who have usufruct rights in communal lands known as Ejidos. This type of communal land was established by the federal government in response to agricultural land petitions by landless peasants between the 1930s and 1980s [72].

Xalapa's PHS program called Acuerdos por Nuestra Agua (ANA) (formerly known as Programa de Compensación de Servicios Ambientales del río Pixquiac or PROSAPIX), was launched in 2008 following the LMF-PHS model to cover Pixquiac sub-watershed [73]. The program is administered by a local non-profit Senderos y Encuentros para un Desarrollo Autónomo Sustanable (SENDAS) and has a governing body (Comité de Cuenca del Río Pixquiac or COCUPIX) with greater participation in decision-making from local stakeholders, including private landowners, ejidatarios and water users [68,73]. It is important to highlight the participation of ejidatarios from the Ejido San Pedro Buenavista and Ejido Agua de Los Pescados [68].

Xalapa's LMF-PHS receives funding from CONAFOR, the City of Xalapa, and CMAS Xalapa. Water users contribute to the program through the water bill which iseither paid to CMAS Xalapa or through direct voluntary contributions to the program [68]. However, the program budget is negotiated annually as it is not formally entitled in the city budget. The program currently covers an area of about 1098 ha [68].

The annual compensation in both programs is about $\$ 1100 \mathrm{MXN} /$ ha $(\sim 50 \mathrm{USD} / \mathrm{ha}$ in 2019) for forested lands only [68]. SENDAS offers technical assistance to enrolled landowners in addition to the cash payment [73]. Landowners are required to do forest conservation practices that include fencing, fire control, harvest prevention, and restoration [11]. No other land uses are allowed in PHS program paid areas besides forest conservation $[11,68]$. However, SENDAS has a broader approach that includes "environmental restoration, productive reconversion or the development of production alternatives with an orientation towards sustainability" [73] (p. 83). FIDECOAGUA launched the program Adopt a Hectare, Adopta una Hectárea, in 2011 to look for additional support for forest restoration from local companies [68]. Both programs enroll private landowners and communal-land landowners, but SENDAS' approach has greater involvement of these actors (and water users) in planning and decision making [68,73].

\subsection{Reciprocal Water Agreements (RWA) in Central Valle del Cauca, Colombia}

Deforestation and forest degradation in Colombia due to industrial agriculture, pastures for cattle, mining, and development projects are of great concern for conservationists and governmental institutions, given that the forest area has been significantly reduced [74-77]. For instance, the tropical dry forest covers less than $1 \%$ of its original area and is considered threatened in the plains and Central Andes [78]. The rate of deforestation has increased in the last decades $[79,80]$ due to economic activities incentivized by the national government $[77,78]$ and illegal armed groups [59,74,75].

It is worth noting that, unlike other tropical countries in the region, Colombia faces a long-time social conflict between the Colombian army, left-wing guerrillas, right-wing armed groups, and local and foreign drug traffickers [81] that has shaped the patterns of deforestation and conservation strategies $[59,74,75]$. Illegal armed groups have historically controlled the economic activities and type of actors that can access and use forested areas and national parks $[74,81]$. Across different regions, conservation activities and the exploitation of natural resources are dependent on who the armed actor is and if there has been a settlement between armed actors that allows for the exploitation of natural resources [81]. 
To counteract deforestation and forest degradation, the national government has issued forest use restrictions, established natural parks of local and national interests, controlled deforestation through the environmental agencies at the local, state, and national level, and incentivized conservation through payment for ecosystem services schemes $[59,78]$. The use of market-oriented schemes in conservation started in the late 1990s in Colombia [78], yet there had not been a state policy to guide the use of PHS-like schemes until mid2017, after the peace agreement was signed between the government and one of the left-wing guerrillas [82]. The Peace Accord between the Colombian government and Fuerzas Armadas Revolucionarias de Colombia-Ejército del Pueblo or FARC-EP, addressed a legislative gap on the use of PHS-type schemes and allowed the implementation of schemes reducing legal and administrative barriers for those tenants and landholders with no land title [83].

There have been several government and non-profit efforts to implement PHS-like schemes in Colombia $[59,82,84,85]$. Although the traditional cash payment is still the most used tool in the country (and the world), an innovative approach was developed by the international non-profit RARE [86]. Reciprocal Water Agreements, Acuerdos Recíprocos por el Agua or ARA, were proposed as a mechanism to incentivize conservation of forests through non-cash, in-kind payments including farm materials, agricultural inputs, and household assets [87].

By using non-cash, in-kind payments, PHS program administrators seek to achieve "crowding in" forest conservation and sustainable agricultural practices while avoiding "crowding out" intrinsic motivations for conservation [86]. This model has been used in other countries such as Ecuador [87], Bolivia [88], Peru [89], and India [90] with noteworthy outcomes in community cohesiveness, social capital, and community governance. The ARA model was initially implemented in at least 18 locations in Colombia between 2012 and 2015, yet few schemes are still functioning [85,86].

The City of Guadalajara de Buga (110,000 population), located in Central Valle del Cauca, has two ARA programs called (1) Programa de Incentivos para la Conservación de Bosques del Río Guadalajara (PICB Buga) and (2) Acuerdos Recíprocos por el Agua de la Cuenca del Río Sonso (ARA Sonso), which have been functioning since 2012 and 2013 respectively. The first program, PICB Buga, is administered by the local water utility organization, Aguas de Buga, and the program covers the Guadalajara River sub-watershed. The second program, ARA Sonso, is administered by the state environmental agency, Corporación Autónoma Regional del Valle del Cauca or CVC, and the program covers the Sonso River watershed.

To fulfill our interest in comparing the different types of PHS program administrations, we focus on PICB Buga whose administration consists of a mixed private-public ownership organization. The corporate governance of Aguas de Buga has representation from the City of Buga and private shareholders in the General Assembly of Shareholders (GAS), yet the local government has strong participation in program budget allocation. Buga's ARA program receives funding from a surcharge on water bills in the City of Buga.

The program currently covers an area of about 11.62 ha of conservation and 63.19 ha in integral management in the Guadalajara River sub-watershed (Bug03). It is important to highlight that we did not consider the scale of the programs (i.e., program coverage) to match the case studies in Mexico, as our focus was on the administration of PHS and the participation of PHS stakeholders in program decision making. The annual compensation is about $350,000 \mathrm{COP} / \mathrm{ha}(\sim 100 \mathrm{USD} / \mathrm{ha}$ in 2020) for forested lands and reforestation, which is paid in farm supplies, materials for forest restoration, or household assets. No technical assistance is offered with the program payment, but technical studies are offered (e.g., topographical land studies).

Buga's ARA program enrolls private landowners only and they are required to isolate and protect enrolled lands with improved land management practices, such as barbed wire and fencing [86]. Contracts are "signed between the local institution and landowners through a one-on-one negotiation where commitments from both sides are clearly estab- 
lished" [86] (p. 31). Non-cash, in-kind transactions, enrolled areas in the program, and farm activities are agreed upon between the program administrator and the landowner. Table 1 summarizes the case studies.

Table 1. Main PHS program characteristics in the three case studies.

\begin{tabular}{|c|c|c|c|}
\hline & Coatepec-Mx & Xalapa-Mx & Buga-Co \\
\hline Population & 85,000 & 425,000 & 110,000 \\
\hline Sub-watershed & Gavilanes & Pixquiac & Guadalajara \\
\hline $\begin{array}{l}\text { Environmental } \\
\text { challenges }\end{array}$ & $\begin{array}{c}\text { High deforestation rates, } \\
\text { droughts }\end{array}$ & $\begin{array}{c}\text { High deforestation rates, } \\
\text { droughts }\end{array}$ & $\begin{array}{l}\text { High deforestation rates, } \\
\text { droughts, land slides }\end{array}$ \\
\hline PHS program & $\begin{array}{c}\text { Fideicomiso Coatepecano para } \\
\text { la Conservación del Bosque y el } \\
\text { Agua (FIDECOAGUA) }\end{array}$ & Acuerdos por Nuestra Agua (ANA) & $\begin{array}{c}\text { Programa de Incentivos para la } \\
\text { Conservación de bosques del Río } \\
\text { Guadalajara (PICB Buga) }\end{array}$ \\
\hline Began operations in & 2002 & 2008 & 2012 \\
\hline Program administrator & $\begin{array}{l}\text { FIDECOAGUA } \\
\text { (local government) }\end{array}$ & $\begin{array}{l}\text { SENDAS } \\
\text { (non-profit) }\end{array}$ & $\begin{array}{l}\text { Aguas de Buga } \\
\text { (water utility) }\end{array}$ \\
\hline Area in PHS program & 1548 ha & 1098 ha & $\begin{array}{l}11.62 \text { ha conservation } \\
63.19 \text { ha integral manag. }\end{array}$ \\
\hline Payment per hectare & MXN 1100 (USD 85) & MXN 1100 (USD 85) & COP 350,000 (USD 100) \\
\hline Type of payments & Cash & $\begin{array}{l}\text { Cash, in-kind transactions, } \\
\text { training, technical assistance }\end{array}$ & $\begin{array}{l}\text { In-kind transactions, } \\
\text { technical studies }\end{array}$ \\
\hline Eligibility criteria & $\begin{array}{l}\text { Amount of forest, } \\
\text { confirmation of property } \\
\text { right by land title, type of } \\
\text { ecosystem }\end{array}$ & $\begin{array}{l}\text { Amount of forest, confirmation of } \\
\text { property right by land title, type } \\
\text { of ecosystem }\end{array}$ & $\begin{array}{l}\text { Amount of forest, area for } \\
\text { reforestation, confirmation of } \\
\text { property right by land title }\end{array}$ \\
\hline Eligible land uses & $\begin{array}{l}\text { Forest conservation, forest } \\
\text { restoration }\end{array}$ & $\begin{array}{l}\text { Forest conservation, forest } \\
\text { restoration, sustainable } \\
\text { agriculture, shade-grown coffee }\end{array}$ & $\begin{array}{l}\text { Forest conservation, } \\
\text { forest restoration }\end{array}$ \\
\hline Monitoring by & FIDECOAGUA & SENDAS \& community & Aguas de Buga \\
\hline
\end{tabular}

\section{Methods}

Based on previous studies of PHS impacts on the social and ecological attributes of La Antigua River watershed $[11,68,91]$, we built a list of institutional actors and conducted semi-structured interviews with 13 organizations in 2019 to understand the history and dynamics of the PHS programs in Coatepec and Xalapa. For the third case study, we started by meeting with the PHS program administrator in summer 2019 and organized a field trip to meet enrolled landowners and visit their properties. Then, we used purposive and snowball sampling methods to collect institutional data [61,92]. In spring 2020, we started with the PHS program administrator and the environmental agency official who managed PHS-type programs in the Central Valle del Cauca and asked them to recommend organizations that work, or have worked, with Buga's PHS program in the past. We chose this approach because there was no peer-reviewed or gray literature available for this case study. We built a list of six key informants which was updated after an interviewee suggested a potential stakeholder. Table 2 shows the types of institutional actors we interviewed in each case study.

For each case study, the institutional interviews provided details about (1) the institutional activities related to water use, management, and conservation, (2) the participation in and/or contribution to PHS programs, (3) goals, benefits, and barriers to participation in PHS programs, and (4) interviewees' role in PSH program decision making. The list of interviewees included local government and park agency officials, local non-profit staff, water utility staff, researchers from local universities, the PHS local administrators, and an industry representative. All interviews were conducted in Spanish, audio-recorded and transcribed verbatim by a native Spanish speaker. 
Table 2. Key informant interviewees from each case study.

\begin{tabular}{ccccc}
\hline & $\begin{array}{c}\text { Coatepec } \\
\text { (Coa) }\end{array}$ & $\begin{array}{c}\text { Xalapa } \\
\text { (Xal) }\end{array}$ & $\begin{array}{c}\text { Buga } \\
\text { (Bug) }\end{array}$ & Total \\
\hline $\begin{array}{c}\text { Local government } \\
\text { Environmental/Park agency }\end{array}$ & $*$ & 1 & 2 & 3 \\
Non-profit ** & 2 & 1 & 1 & 2 \\
Water utility & & 3 & $*$ & 7 \\
University ** & 1 & 1 & 1 & 2 \\
PHS administrator & 1 & 1 & & 3 \\
Industry & 1 & & 6 & 1 \\
\hline Total & 5 & 8 & & 19 \\
\hline
\end{tabular}

Note: * The interviewee is also the PHS administrator. ${ }^{* *}$ Where stakeholder headquarters are located, but organization (and interviewee) has worked on both Coatepec's and Xalapa's PHS programs.

Initial coding was deductively conducted according to emerging themes: (1) benefits and challenges of participating in PHS programs, and (2) participation/role in PHS program decision making. We refined these categories into: (1) modes of stakeholder engagement in PHS decision making, and (2) perceived impacts of stakeholder engagement on trust and power. NVivo 12.1 for Windows 8 was used to code qualitative data into these analytical categories. Our discussion follows Senecah's (2004) TOV components (access, standing, influencing) to understand how different modes of stakeholder participation shape participation outcomes in PHS program decision making. Interview protocols received IRB approval (Syracuse University IRB No. 19-153 and University of New Hampshire IRB No. 7046). Background information for this paper was based on data from the project "Experimental Frameworks for Evaluating Net Effects of Hydrologic Service Payments on Coupled Socio-Ecohydrologic Systems in Mexico" and the doctoral dissertation "Stakeholder Participation in Payment for Hydrological Services Program Decision Making: Public Participation, Collaborative Learning, and Trust in Environmental Decision Making".

\section{Results}

\subsection{PHS Program in the City of Coatepec, Central Veracruz, Mexico}

\subsubsection{Modes of Stakeholder Engagement in PHS Decision Making}

Institutional, technical, administrative, and legal factors have supported the successful operation of a PHS scheme in Coatepec since 2002. FIDECOAGUA, Coatepec's trust fund, has a governing body (interinstitutional committee) where five members represent the City of Coatepec (i.e., the city's mayor), CMAS Coatepec (i.e., CMAS director), CONAFOR (i.e., official from CONAFOR Veracruz), water users, and the industrial sector (i.e., Nestlé). Representation of local stakeholders on the governing body is a form of participation. FIDECOAGUA's committee makes decisions about program budget allocation, funding sources, eligible activities, and forested areas for payment. The committee also proposes other environmental programs to support the trust fund, develops PHS policy guidelines, and presents program auditing to the city council.

Alongside the use of an interinstitutional committee, FIDECOAGUA uses a top-down approach to stakeholder participation that is focused on one-way communication to educate the public about the existence of the program and to inform landowners enrolled in PHS about decisions and program conditions. FIDECOAGUA has focused on communicating its social and environmental goals related to contributing to upstream landowners' wellbeing, incentivizing forest conservation, and improving water quantity and quality. The program administrator has used environmental awareness campaigns aimed at school-age children who are perceived to be potential environmental stewards and information spreaders. A local government representative explained that:

"We even thought of creating a [watershed education] model where the drainage area could be seen and they [kids] could be involved, because people see, they understand the 
visual display better [...]. We try to reach the schools because they are the first ones who educate children in the families. We are looking for communication alternatives for people to know about the program" (Coa04).

The PHS program administrator has also informed and consulted with enrolled landowners to gather information about landowners' household needs and preferences of alternative income sources. In addition, FIDECOAGUA has used skill-based courses to train enrolled landowners in sustainable agricultural practices and environmentally friendly crops, such as orchid cultivation, to engage participants in achieving environmental goals and securing compliance with forest conservation.

\subsubsection{Perceived Impacts of Stakeholder Engagement on Trust and Power}

FIDECOAGUA's governance scheme to administer public funds was perceived in two opposite ways by our respondents. On the one hand, an individual involved in program administration, a non-profit staff person, and an industry actor stated that having a fivemember technical committee enhanced decision making by allowing the voices of different organizations to be heard and able to make decisions about program budget allocation. A non-profit representative argued that:

"I think that a governance space with those schemes or under that scheme [FIDECOAGUA's] is much richer. In other words, plurality in decision making will always be better [...]. But I think that moving towards a decision making and governance scheme like Coatepec's would have to be the most suitable" (Coa01)

Some institutional interviewees agreed that using an interinstitutional committee to make key decisions was important to be informed about program outcomes and oversee the activities of the PHS program administrator. The top-down one-way communication approach of Coatepec's PHS program was perceived as trustworthy by those committee members who can participate in program decision making and have access to program auditing. For instance, when we asked the representative of the industry sector about why a big corporation was contributing to the PHS program, the interviewee replied that:

"Because it's linked to the objectives of the company. This wasn't only due to our commitment, but in our corporate culture and within the objectives it's precisely the commitment to the environment. So, we saw that participating [in the PHS program] with an institution that is responsible, that has the certainty that [the money] is going to be well used. That there'll be a benefit from it" (Coa02).

This statement shows that the perception of accountability is key for the participation of the industry in program contribution and decision making. An interviewee involved in program administration also highlighted that informing committee members about program results was key to program transparency and to maintaining the trust of other committee members:

"Because we aren't in a rush to hide anything. The companies have some confidence [in us] because we're telling them, we're even inviting them to various activities so that they can see where [the money] is going. [...]. We try to be intermediaries and not to handle in the money, less problems for us, more transparency. So that gives some kind of certainty to the company because we are frequently informing all what is about the committee" (Coa04)

On the other hand, FIDECOAGUA's technical committee was perceived as not representative of Coatepec's civil society, due to the lack of participation of other types of stakeholders (e.g., academia, non-profits, and enrolled landowners) and lack of mechanisms for two-way communication and program feedback. For instance, a researcher at a local university argued that:

"FIDEOAGUA, has few members and the main ones are the president, the mayor, the director of CMAS Coatepec, and some people from the local bank where the trust fund is put, and some very well-known entrepreneurs in the city. But they never invite [researchers] to the committee" (Coa03). 
In general, FIDECOAGUA's one-way communication approach to public participation was perceived as insufficient by many interviewees because the program administrator does not engage the broad public in meaningful ways. First, the PHS program's communication mechanism is focused on informing and/or educating children about the program and has not reached a broader audience. A researcher argued that "in the case of FIDECOAGUA, the only involvement approach of water users is through their children. [...]. Many people don't know, that is, most residents aren't aware [of the PHS program]. So, that's a pending task" (Coa03).

Second, FIDECOAGUA seems not to be responsive to requests from local organizations (i.e., academia and non-profits) to accept the participation of other PHS stakeholders in program decision making. A non-profit representative argued that "FIDECOAGUA has a committee that is made up of different actors [...] and they also told us in that administration (2018-2021) that they were going to invite us, but it never happened" (Coa05). Third, communities often marginalized from PHS decision making (i.e., enrolled landowners) had not participated in program design and decision making until 2018, when new FIDECOAGUA staff adopted a targeted approach to address community needs but retained the top-down administration approach.

According to several interviewees, the top-down one-way communication approach used to inform the broad public was perceived as untrustworthy. Contrary to the committee members' perception of the program's transparency, interviewees affiliated with local universities and non-profits argued that the City of Coatepec and the program administrator were not trustworthy. According to our non-committee member interviewees, there was a general perception of mistrust in governmental institutions among citizens. A local researcher who conducted an evaluation of Coatepec's PHS program stated that enrolled landowners tend to distrust the local government and the PHS program administrator:

"The management of the PHS program, in general, was ranked bad. They [landowners] don't get it [the money] or isn't enough. They don't receive the payment or is insufficient. It [the program] doesn't have enough coverage or the information they have isn't enough. They distrust, they say that they distrust the government" (Xa102).

In general, Coatepec's PHS program shows a more top-down one-way communication approach to stakeholder participation, which involves few local stakeholders in PHS program decision making. FIDECOAGUA's committee members have a voice in the PHS program's budget allocation and can influence program outcomes by investing program payments in prioritized areas. However, several PHS stakeholders were excluded from FIDECOAGUA's governance scheme, giving them little power to influence decision making. One of the committee members argued that the local universities should participate in the committee to be able to inform decision makers about program's impacts on social and environmental variables:

"[Academia] has a lot of high-quality information that needs to be translated so the organized citizen groups, the society in general, and especially the government officials who make decisions can get the information and then be able to justify why a [PHS] scheme is necessary or to continue with a PHS program. So, academia needs to be in these governance schemes" (Coa01).

The decision space for non-committee members in the PHS program's decision making was perceived as limited by several respondents. One of the non-profits who had been working on community monitoring, rapid rural appraisal, and collaborative planning in La Antigua River watershed (both Coatepec and Xalapa) claimed that Coatepec's PHS program governance scheme needs to be adapted to include one-way and two-way communication mechanisms to improve citizens' awareness about the PHS program and their power to influence program outcomes:

"I believe that the program will benefit to the extent that the civil society can know its results and its intentions. There should be at least a part of communication, a form to communicate the principles, the results, the sources, the scientific challenges $[\ldots]$. Once it happens, [...] specific groups can have deeper discussions, and there will be a connectivity 
of social participation in the votes for the PHS initiatives, in the votes of representation, in the audiences. That active participation will help a lot to shape where [the program] goes" (Xal03).

\subsection{LMF-PHS Program in the City of Xalapa, Central Veracruz, Mexico}

\subsubsection{Modes of Stakeholder Engagement in PHS Decision Making}

The local non-profit SENDAS and a local university started an integral watershed co-management project in 2006 that used participatory action research (PAR) to engage community members in environmental planning. The PAR project initially sought to understand the socioenvironmental reality of the watershed and then engaged local actors in awareness campaigns, reforestation, and designing strategies to support local livelihoods and forest conservation.

In response to citizen discomfort about the increase in water fees and persistent waterrelated issues, the City of Coatepec and CMAS Xalapa endorsed SENDAS' proposal of creating the Pixquiac River Compensation for Ecosystem Services program, Programa de Compensación por Servicios Ambientales del río Pixquiac, or PROSAPIX, in 2008. The PHS program initially paid forested lands, but SENDAS' approach to integral watershed management broadened PROSAPIX activities and went beyond forest conservation to support forest management, agroforestry systems, environmental restoration, productive reconversion, good agricultural practices, sustainable agriculture, and the like. The PHS program was later revised to incorporate the broader approach to watershed management. In 2016, this new program was renamed Agreements for Our Water, Acuerdos por Nuestra Agua, or ANA, which looked beyond a unique economic tool to incentivize conservation of biodiversity and ecosystem services.

To administer the PHS program, SENDAS created the Pixquiac River Watershed Committee (COCUPIX) which has participation of three local governments, local universities, ejido authorities, federal agencies, local non-profits, water users, farmer associations, PHS enrolled landowners, and other citizen groups. Through COCUPIX, SENDAS has worked on PAR, collaborative environmental planning, PHS design and implementation, and program monitoring. Among with the tasks related to the PHS program, the committee makes decisions about PHS program budget allocation, sets the guidelines for landowner eligibility in the PHS program, and conducts community monitoring to check for the enrolled landowners' compliance to forest conservation.

Through COCUPIX, SENDAS has used one-way and two-way communication mechanisms to engage stakeholders in PHS program decision making and watershed planning. For instance, the organization has used environmental awareness campaigns, PHS advertising campaigns, and public hearings to inform and educate the public about ANA program, water and forest management, and environmental projects in Pixquiac River watershed. Through training in local species identification and community research, SENDAS has also "increased ejidatarios' awareness about communal lands, about forests, about their conservation, they also talk about small mammal conservation, bird conservation, etc." (Xa107). On the other hand, SENDAS, with the assistance of local organizations, has also encouraged participation of stakeholders through collaborative planning, participatory action research, community monitoring, and shared decision making.

SENDAS' approach to stakeholder participation shows a more bottom-up approach that has allowed the engagement of diverse local actors in design, implementation, and evaluation of the PHS program and the watershed management plan. Bringing diverse stakeholders to PHS program decision making was also perceived as a good model for comanagement and community conservation of forests. A representative of the national park agency acknowledged SENDAS' role in administering the PHS program and incentivizing the participation of enrolled landowners in "shared management":

"COCUPIX is a model. Well, SENDAS comes from a long tradition of working in the community field, very committed to the [economic] resource, to the people. Many of them [SENDAS staff] live in the same area they are protecting. So, they also have 
a personal interest and have had the patience to work with the community to do the management, actually the shared management of the water resource of Pixquiac River watershed" (Xal01).

\subsubsection{Perceived Impacts of Stakeholder Engagement on Trust and Power}

Working towards co-management of Pixquiac River watershed and shared decision making has involved continuous training and collaboration to strengthen community capacities for environmental planning and decision making. Several interviewees argued that SENDAS' approach to stakeholder participation in PHS decision making was noteworthy and useful to encourage citizen empowerment. For instance, a researcher at a local university argued that:

"In the case of Xalapa and the program with SENDAS, SENDAS has been pioneering, but again the decision making is a negotiation, isn't it? Obviously SENDAS is independent, SENDAS created the COCUPIX committee, and they were the leaders of it, but [the committee] has already been appropriated by the local communities and they are putting pressure on the local government through it" (Coa03).

SENDAS' approach to stakeholder participation was perceived to be trustworthy by several respondents. An interviewee argued that the role SENDAS plays in the administration of economic incentives was key for securing payments to landowners and overseeing program budget allocation: "Well, the advantage is that they [the program] do have regular payments and, so, they have been able to move forward. SENDAS and PROSAPIX, over there in Xalapa, it's technically really good to have an NGO overseeing, it's excellent" (Coa03). Another interviewee seconded this perception on SENDAS' role by acknowledging that the non-profit reflects social control over public resources: "I think that the participation of SENDAS is important, not as SENDAS, but as civil society, a social auditing" (Xal01). However, trustworthiness in the PHS program might also depend on the role CMAS Xalapa has in administering public resources before they are allocated to the program. According to several interviewees, Xalapa residents do not trust the local government and the water operator:

"Unfortunately, CMAS has a very bad reputation, and even though things are improving right now, it has been years and years of being the petty cash, to take money from it. So, it's fighting against this reputation [...]. I would say like inviting citizens who could represent Xalapeños, but not politicians. That is to move away the committee and the PHS work from politics, and that CMAS wasn't in charge of managing the money" (Xa105).

To foster trust in the PHS administration, the interviewees agreed that transparency and social auditing were important. The role that diverse citizens, citizen groups, government agencies, non-profits, and ejido authorities have in program decision making and auditing through COCUPIX was highlighted as a broader representation of PHS stakeholders. SENDAS incentivizes the auditing of the PHS program budget and community monitoring of landowners' compliance with agreed contracts. In general, the committee led by SENDAS was perceived as trustworthy and as key to securing PHS stakeholder participation in environmental decision making: "It's also important to say that the watershed committee is the governing body that promotes a more equitable decision making, so decisions are made based on environmental criteria of the watershed management plan that we built [altogether]" (Xal04).

However, SENDAS' approach to stakeholder participation was perceived to be limited by an interviewee who works for the local government on awareness campaigns in the urban and rural areas. According to her, the lack of knowledge about the existence of Xalapa's PHS program among urban citizens shows that the PHS program approach to stakeholder participation is limited by not engaging more stakeholders (i.e., water users) in the committee:

"The citizens have almost no participation, that's the truth. The program is very restricted, and not because they are doing it so, but I insist on the same problem, lack of awareness, it's limited [...] citizenship as such isn't involved" (Xal05). 
In response to this limitation, a researcher at a local university stated that SENDAS is currently working on improving its awareness campaigns to both inform the public and convince urban water users of voluntarily contributing to the PHS program, "SENDAS has had some awareness campaigns. They're already moving towards a voluntary payment program and with that, obviously, you must connect with water users and convince them that it [the program] is worth it. [...]. They've been successful" (Coa03).

In conclusion, the SENDAS PHS program administration reflects a more bottom-up deliberation and co-production approach to stakeholder participation. The benefits of this approach were extensively acknowledged by our interviewees when ideas of trust and transparency were emphasized in the type of administration and auditing of the program. SENDAS works towards more inclusive participation by conducting participatory methods and action research to engage the public in program decision making and co-management. Yet, SENDAS needs to improve its methods to reach out to other types of stakeholders and/or the public: "being that said, program and services communication to citizens needs to be there. Each person that pays a water bill should have access to the information that what she pays goes to forest conservation" (Xal03).

\subsection{PICB Program in the City of Guadalajara de Buga, Central Valle del Cauca, Colombia}

\subsubsection{Modes of Stakeholder Engagement in PHS Decision Making}

The PICB program in the City of Guadalajara de Buga is considered one of the first experiences of non-cash, in-kind PHS programs in Colombia. The program design is built on the notion of 'Reciprocal Water Agreements for People and Nature" of the American non-profit organization RARE that aims to incentivize pro-social and pro-environmental behaviors among natural resource-dependent communities through the "Pride methodology". The Pride methodology focuses on social marketing to foster environmentally friendly responses and provide alternative household incomes to motivate communities to protect biodiversity and ecosystems. The methodology also seeks to foster co-responsibility and community cohesiveness by promoting community spaces for collaboration.

The program initially started as Acuerdos Recíprocos por el Agua del río Guadalajara and was administered by RARE, Aguas de Buga, and CVC. Then, it was renamed Programa de Incentivos para la Conservación de Bosques del Río Guadalajara (PICB Buga) to focus on forest conservation and restoration when the water utility began administering it in 2014 without RARE leadership. According to the PICB administrator and a non-profit staff, the operation of PICB Buga consists of a nine-stage process that allows the program administrator to establish the eligibility of a potential paid area, make payments to landowners, and monitor compliance with conservation activities.

To discuss key decisions in the PHS program's administration, Aguas de Buga created a technical committee in which several institutional stakeholders participate: The City of Guadalajara de Buga, through the Secretary of Agriculture and Development and the Secretary of Municipal Planning; The state environmental agency CVC; The non-profits Corporación Ambientalista Esperanza Verde and Fundación Tierra Nueva; The Departmental Museum of Natural Sciences-INCIVA; and Buga Environmental Policy Force. The City of Guadalajara de Buga does not significantly support and/or assist in coordinating interinstitutional activities, according to several interviewees. The committee has annual meetings to make decisions about program budget allocation and coordinates institutional efforts to strengthen the PHS scheme, such as conducting environmental awareness campaigns, the developing of biophysical studies to inform the program, assisting in monitoring program outcomes, or controlling destructive activities in the watershed.

To engage diverse stakeholders in the PHS program, Aguas de Buga has mostly used one-way communication methods, especially with the public. According to our interviewees, the program administrator has used environmental awareness campaigns (e.g., water conservation and efficiency, ecological knowledge trivia), public hearings to inform about program outcomes, public announcements for accepting new landowner applications to the program, and trainings in forest management, etc. An interviewee 
who works for the City of Buga argued that the program administrator has used several communication strategies to foster better water use practices among both rural and urban citizens, and that the PHS program has been successful in reaching out to a broader public:

"They have generated communication strategies, [...] they haven't only done it in the rural area, but also in the urban area. People have already become aware of where the water comes from, how it comes, when it comes at lower levels, what should be done. The communication strategy has been very effective, let's say that what PICB program has is a very good way of communicating. There have been some very well-designed communication strategies that have impacted people [...]. People are more aware, because the program has engaged people, the [water] users, the final consumer of the resource. They've already been involving them in [water use and conservation], they've generated communication and information strategies, but also about education, strengthening those [rural-urban] links" (Bug09).

\subsubsection{Perceived Impacts of Stakeholder Engagement on Trust and Power}

The technical committee makes key decisions about budget allocation, eligible lands, and the prioritization of areas for conservation. A representative of the environmental agency argued that, through the committee, decisions are made in a democratic way and that the scientific (technical) knowledge supports decision making:

"[decisions] are not autarchic in many cases, because people trust the technical knowledge of $\mathrm{CVC}$, but decisions are put on the table and people decide if they agree, or disagree, and what the conditions are [...]. Decisions are made in a participatory democratic form; the committee is also a body for monitoring and transparency" (Bug08).

However, an interviewee who works for the program administrator stated that the committee does not make key decisions about the program because field technicians often know what to do and how the program works:

"We still try to meet in the technical committee, at least once a year. Decisions are not key, because we already know how it [the program] works, and every year we meet with them [the committee members] to make some decisions [...]. We wanted to disperse the administrative function [of the program], but you know, once you understand the dynamic of the city you realize that if you disperse some important functions, it becomes complex sometimes. Thus, we are still the engine, we are still the head of the program [...]. When we need support, we reach out to the town hall, we reach out to other organizations for specific issues, and the committee just meets once a year" (Bug03).

This interviewee emphasized that the committee only makes technical decisions and that the water utility organization, who is the current program administrator and main contributor to the program, makes decisions about the program's budget: "at the budget level, decisions are made internally by the director [of the water utility] and [the program administrator]" (Bug03). This finding was also confirmed by a non-profit representative, who argued that:

"those decisions [budget allocation] are made directly by Aguas de Buga, what they do is only to call us to a meeting like for, they invite us to tell us, yet they made the decisions [...]. Yes, that's their power, one makes suggestions and everything, but actually the program is managed exclusively by Aguas de Buga" (Bug07).

Given the minimal participation of program stakeholders in decision making, Aguas de Buga's approach to stakeholder participation shows a more top-down decision making style in which decisions about program budget allocation are not shared with other local actors, but the administrator does share decisions about technical issues related to environmental awareness, technical studies, or monitoring to optimize organizational resources. According to the interviewees, enrolled landowners do not have access to either the PICB Buga committee or program budgeting, yet decisions about land designation and land uses are made by landowners during the participatory land planning and negotiation of program incentives. 
Though the program administrator's approach to stakeholder participation is principally based on one-way communication techniques, the inter-institutional work by different state agencies and local non-profits has impacted rural communities both socially and environmentally. From one interviewee's perspective, the program's approach to stakeholder participation has been effective in producing positive outcomes:

"[...] some friendship connections have been generated and a new circle, let's say, of conservation has been created. [The program] has also created a different type of friendship connections, that one village didn't know with the other, but now they begin to share certain knowledge and one sees that one supports the other with other things" (Bug09).

Some interviewees agreed that the program has also been effective because it focuses financial resources on landowners' actual needs and because there is shared responsibility between the water utility organization and the landowner in negotiated agreements, payments made, and compliance to agreed activities. However, several interviewees stated that the program produces positive impacts because of the role played by the current chief of the environmental management department:

"Aguas de Buga has a department of natural resources, [name of department chair] has been there for many years [working for the company]. She has always worked pretty coherently, so that has also benefited ARA, that everything in reciprocal water agreements has always been positive, she's had achievements" (Bug10).

Among the measures of program's effectiveness in fostering public responsiveness, the interviewees discussed transparency in the program's eligibility process, the type of payments, and trust in the water utility staff who administers for the program. First, PICB Buga has a rigid eligibility process to participate in the program (i.e., the nine-stage process) that is explained to potential enrolled landowners and city officials:

"They [the city council] thought we were going to benefit our friends, so that was something critical, but we saw it as an opportunity, and we defined a process, perhaps very strict, to show transparency [...]. They thought the NGO [RARE] was going to steal from us, that they were not only getting our water, but our forests as well. They had a negative perception. I think that after eight years [of implementation] we can now show that RARE didn't take anything" (Bug03).

Second, the type of payment is perceived as key to foster trustworthiness in the program. PICB Buga uses non-cash, in-kind payments to incentivize forest conservation and restoration. PICB payments are of two types: ecological restoration and direct incentives. Ecological restoration refers to activities focused on improving land for reforestation and native tree planting, this type of payment is an indirect incentive and not charged to landowners. Direct incentives refer to non-cash payments to fulfill landowners' needs. As discussed by an interviewee, landowners present a list of household and/or farm needs to the program administrator who then buy supplies through a local non-profit:

"The relationship is very direct with the owner, between the owner and the program administration [...]. The advantage here is that when landowners need something, they bring a quote from where they want. The program doesn't pay [landowners]. You bring me the quote, I pay to where you say and the brand you say, not what the institution says. So that has given [the program] confidence. " (Bug09).

Third, several interviewees showed trust in the water utility official who administers the program. Some interviewees who have worked since the program started in 2012 argued that, although the department chair has faced several challenges in convincing public actors (i.e., the city's mayor and the city council) and handled criticism smoothly, she has been able to "hold politics at bay", keeping a good image of the program among the public. Trustworthiness in the program is highly dependent on the water utility staff who manages the PHS program. A non-profit staff argued that many local politicians have tried to block the program because they want to benefit from it: "they [city council] have their political interests, so they didn't find an easy way to put their hands on the program, so they wanted to end the program [...]. She [program director] has taken care of the program a lot, she has protected it". (Bug06). Two other interviewees seconded this 
perception by arguing that the program has gained people's trust by showing transparency and challenging some myths. For instance, an interviewee highlighted that initial trustbuilding requires an understanding of the reasons why people distrust the PHS schemes and institutional programs:

"At the beginning people were forewarned, let's say at the beginning because not anymore. They thought that if you had a conservation system or a reciprocal water agreement you would lose your property [...]. Now people know that they own the land that's legal and they do their planning exercise and leave some area for [conservation]. The project has a good name now" (Bug09).

People's trust in the program has also a social component in the Colombian context. Because many rural communities have suffered the effects of social unrest in the country, trust is fragile between communities and institutional actors. On the one side, rural communities often subsist among different armed actors, making them distrust other community members and institutions. On the other side, institutional absence has deprived rural communities of governmental services and programs, good educational and transportation infrastructure, easy connection with national markets to commercialize agricultural products, public health care services, etc. When discussing some limitations of the PHS program, a government official mentioned the consequences of the war in Colombia for the rural communities and how they have influenced the effectiveness of his work, and he acknowledged that trust is being rebuilt after the peace agreement was signed:

"It's been many years of government negligence, of armed conflict, of negative situations that when these [PHS] programs arrive, they [community] are not receptive. It's because of all that conflict and that state negligence that they have suffered. [...] When we arrived with the programs there were the guerrilla issue, the paramilitary issue, we couldn't develop the programs well precisely because of that situation of public order. But now we have been recovering space and they participate very well. So now we have gained space, but it was really difficult for us in general terms of openness" (Bug10).

Overall, the City of Buga's PIBC program shows a top-down one-way communication and/or consultation approach to stakeholder participation that influences decision power over resources (financial resources, land tenure). The benefits of this approach are perceived in the program's effectiveness to allocate resources, join institutional efforts to address common issues, and maintain decision making power. However, trust in the program is highly dependent on a clear eligibility process, demonstrated respect for landowners' land title, type of payment, and the person who administers the PHS program.

\section{Discussion}

In this paper, we have explored how program administrators and other institutional actors engage diverse publics in PHS program decision making and environmental planning. Our three case studies have shown that diverse types of institutional actors often use different modes of participation to inform and/or engage PHS program stakeholders in environmental decision making (Table 3), though one-way communication is frequently used $[15,18,93]$. In our case studies, the one-way communication approach to stakeholder participation is often used to inform and/or educate the public about the existence of the PHS programs and, in two of the cases, to inform enrolled landowners about program decisions that are made by either the program administrator or inter-institutional committees.

In the literature in ecosystem services, one-way communication mechanisms are frequently associated with top-down environmental decision making [51,94-97] in which external organizations or outsiders (e.g., governmental organizations, industries, nonprofits) hold decision making power about program budget allocation, program eligibility, type of payments, and so forth $[53,57,58,98,99]$. Communities and non-state actors are not often involved in decision making, and there is low awareness and/or interest in environmental programs, distrust in governmental agencies and foreign organizations, and conflict between local actors [15,21,34,100]. 
Table 3. Agency and modes of engagement across case studies.

\begin{tabular}{cccc}
\hline & $\begin{array}{c}\text { FIDECOAGUA } \\
\text { Coatepec, Mexico }\end{array}$ & $\begin{array}{c}\text { ANA } \\
\text { Xalapa, Mexico }\end{array}$ & $\begin{array}{c}\text { PICB } \\
\text { Buga, Colombia }\end{array}$ \\
\hline Agency & $\begin{array}{c}\text { Local government through } \\
\text { FIDECOAGUA } \\
\text { interinstitutional committee }\end{array}$ & $\begin{array}{c}\text { Non-profit, citizen groups, } \\
\text { government agencies, farmer } \\
\text { associations, enrolled landowners in } \\
\text { PHS through COCUPIX committee }\end{array}$ & $\begin{array}{c}\text { Water utility through PICB } \\
\text { technical committee }\end{array}$ \\
\hline $\begin{array}{c}\text { Modes of engagement } \\
\text { Environmental awareness } \\
\text { campaigns, public hearings, } \\
\text { informing general public, } \\
\text { training, and } \\
\text { Approach to stakeholder } \\
\text { participation }\end{array}$ & $\begin{array}{c}\text { Environmental awareness campaigns, } \\
\text { public hearings, training, } \\
\text { participatory action research, } \\
\text { co-management, collaborative } \\
\text { planning, shared decision making, } \\
\text { and community monitoring }\end{array}$ & $\begin{array}{c}\text { Environmental awareness } \\
\text { campaigns, public hearings, } \\
\text { public announcements, } \\
\text { training, technical studies, } \\
\text { consulting, technical } \\
\text { committee }\end{array}$ & $\begin{array}{c}\text { Top-down one-way } \\
\text { communication and } \\
\text { consultation }\end{array}$ \\
\hline
\end{tabular}

The case studies in Coatepec, Mexico and Guadalajara de Buga, Colombia support this common finding, yet the use of an inter-institutional committee for shared decision making and policy consistency between governmental agencies and non-state organizations might suggest that their approach deviates from a simple top-down one-way communication and/or consulting to incorporate characteristics of top-down deliberation and/or co-production $[30,31]$. However, it is worth noting that many non-committee member interviewees from Coatepec's and Buga's PHS programs claimed that participation in PHS program committee is limited and that communities often marginalized from decision making (i.e., enrolled landowners and household water users) do not participate in those decision spaces.

Critical scholars of public participation have called for attention to the ways mainstream participation often co-opts participation and, instead, silences minority voices by imposing other interests and goals $[37,101,102]$. Even though program administrators in these two case studies asserted that enrolled landowners were always heard, the programs' approaches to stakeholder participation were focused on one-way communication to inform and/or educate landowners and on consulting to collect information about landowners' needs and interests.

Several scholars have criticized this approach to participation for its assumption that a well-informed public can understand environmental projects better and support them to achieve social and environmental goals $[16,27,103]$. Under this assumption, the publics' lack of support for environmental programs and/or commitment to them is rooted in low levels of knowledge (or information) about program goals and requirements. In the context of this "deficit model", PHS program administrators often work on marketing strategies (i.e., PICB Buga) or environmental awareness campaigns (i.e., PHS Coatepec). The participation of landowners in decision making is limited to land planning and the negotiation of payments, but they have little power to influence payment amount, budget allocation, eligible lands, or monitoring compliance.

PHS program administrators have also used two-way communication mechanisms to engage stakeholders in program decision making; however, SENDAS has gone beyond formal interinstitutional committees to implement a broad set of participatory methodologies and techniques, such as PAR, collaborative planning, and community monitoring (Table 3). SENDAS has joined institutional efforts with governmental agencies and community groups to develop more participatory ways to engage PHS program stakeholders in decision making. For instance, a study in La Antigua watershed highlights that "research conducted in Pixquiac has been paired with specific actions that seek to maintain the academic interest with the expectations and needs of communities in the watershed" [73] (p. 78). 
The administration approach of Xalapa's ANA program responds to criticisms of mainstream public participation through the idea that strategies for the conservation of biodiversity and ecosystem services need to adequately meet local needs and allow meaningful participation [14,31,37,44,45,51,102]. As Pahl-Wostl (2009) has argued, "command-control regime is for example not compatible with an active involvement of stakeholders in the design of policies and management plans. These kinds of considerations have to be taken into account when addressing the dynamics of governance regimes and in particular barriers to change" [97] (p. 355).

SENDAS' approach to stakeholder participation resembles a bottom-up deliberation and/or coproduction approach in environmental decision making and production of knowledge [31] that allows for greater stakeholder participation, including PHS enrolled landowners, farmer associations, citizen groups, and water users [7,39-41,51,96,104]. Within SENDAS' approach, environmental collaborative management highlights the increasing role of diverse stakeholders in working together to solve common problems and joint decision making [12,18,20-22].

It is important to acknowledge that, despite the approach to stakeholder participation that a program administrator uses, the three primary organizations have been successful in implementing the PHS schemes in their watersheds, and have been able to navigate social, political, and financial issues associated with local, specific contexts. The diversity of approaches to public participation often responds to the scholarly need for designing more participatory methods to engage the public in environmental decision making [30,31] and the perceived assumption that meaningful participation is needed in an environmental democracy [13,14,18,22].

However, some scholars have criticized these assumptions by arguing that "mainstream" participation can, in fact, silence the voice of communities often marginalized from decision making by imposing outsiders' interests, neglecting the local context and overriding local forms of environmental governance $[37,101,102]$. Although relevant to improve the participation of specific stakeholders and non-state auditing of PHS programs globally $[39,41,50,57,105]$, the use of interinstitutional committees or multi-stakeholder committees requires special attention on how mainstream participation can coopt local contexts [37,102,106]. Sprain et al. (2011) and Sprain (2016) have used the concept of "wickedness" to argue that public participation in environmental decision making is a wicked problem, given that reaching consensus can neglect existing conflict and dissent and contribute to deepening the marginalization of minorities from decision making. A critical review of the role of participation in climate change adaptation discussed that participation can "lead to the cooptation and de-legitimization of marginal people and their dignity as the larger inequitable structures were left untouched, and dissent or conflict was stifled" [37] (p. 84). PHS program administrators interested in the involvement of local stakeholders in environmental decision making need to provide clear mechanisms of participation and assess to what extent decision making power can be shared with local actors [13].

Findings also suggest that building trust in the PHS program and the program administrator is key for program effectiveness, sustainability of local funding, engaging community members' participation in and contributing to the program, producing social and environmental goals, and strengthening the relationship between the community, governmental agencies, and other local actors [13,21,34,100,106]. Using Senecah's 2004 TOV framework has shown that the modes of public participation used by program administrators to engage stakeholders in environmental decision making may have implications for how PHS stakeholders and the general public perceive trustworthiness in PHS programs, governmental agencies and program administrators (Table 4) [13,21,34,100,106]. 
Table 4. Ideas of access, standing, and influence across case studies.

\begin{tabular}{|c|c|c|c|}
\hline & $\begin{array}{c}\text { FIDECOAGUA } \\
\text { Coatepec, Mexico }\end{array}$ & $\begin{array}{c}\text { ANA } \\
\text { Xalapa, Mexico }\end{array}$ & $\begin{array}{c}\text { PICB } \\
\text { Buga, Colombia }\end{array}$ \\
\hline $\begin{array}{l}\text { The access } \\
\text { dimension }\end{array}$ & $\begin{array}{l}\text { Program committee open to } \\
\text { institutional actors } \\
\text { - } \quad \text { One-way communication } \\
\text { Technical assistance and } \\
\text { training }\end{array}$ & $\begin{array}{l}\text { Program committee open to } \\
\text { institutional actors and } \\
\text { community members } \\
\text { One-way and two-way } \\
\text { communication } \\
\text { - Technical assistance and } \\
\text { training } \\
\text { - Join effort with academia } \\
\text { - Hold meetings and forums } \\
\text { - } \begin{array}{l}\text { Hith different stakeholders } \\
\text { communities }\end{array}\end{array}$ & $\begin{array}{l}\text { Program committee open } \\
\text { to institutional actors } \\
\text { - } \quad \text { One-way communication } \\
\text { Committee secretary is } \\
\text { switched between the } \\
\text { committee members } \\
\text { Technical assistance and } \\
\text { training by other } \\
\text { committee members }\end{array}$ \\
\hline $\begin{array}{l}\text { The standing } \\
\text { dimension }\end{array}$ & $\begin{array}{l}\text { - Negotiation of payments } \\
\text { and land uses } \\
\text { Program administrator } \\
\text { considers landowner's } \\
\text { priorities }\end{array}$ & $\begin{array}{ll}\text { - } & \text { Negotiation of payments and } \\
\text { land uses } \\
\text { - } & \text { Open to feedback } \\
\text { - } & \text { Uses scientific knowledge to } \\
\text { - Uses local knowledge to meet } \\
\text { - } \quad \text { Coprogram goals }\end{array}$ & $\begin{array}{l}\text { - } \\
\text { and land uses } \\
\text { - } \quad \begin{array}{l}\text { Program administrator } \\
\text { considers landowner's } \\
\text { priorities }\end{array} \\
\text { Uses technical studies to } \\
\text { inform decision making }\end{array}$ \\
\hline $\begin{array}{l}\text { The influence } \\
\text { dimension }\end{array}$ & $\begin{array}{l}\text { Landowner's farm/land } \\
\text { priorities are heard and } \\
\text { respected } \\
\text { Make decisions through the } \\
\text { committee }\end{array}$ & $\begin{array}{l}\text { - Seek the participation of } \\
\text { diverse stakeholders in } \\
\text { decision making } \\
\text { Encourage co-responsibility, } \\
\text { co-management, shared } \\
\text { decision making, and } \\
\text { community monitoring }\end{array}$ & $\begin{array}{l}\text { Landowner's land/farm } \\
\text { priorities are heard and } \\
\text { respected } \\
\text { Make decisions through } \\
\text { the committee }\end{array}$ \\
\hline Trust and distrust & $\begin{array}{l}\text { Trust between committee } \\
\text { members } \\
\text { Non-committee members } \\
\text { distrust the government and } \\
\text { program administrator }\end{array}$ & $\begin{array}{l}\text { - Trust in the program } \\
\text { administrator } \\
\text { - Community distrusts the } \\
\text { water utility and local } \\
\text { government }\end{array}$ & $\begin{array}{l}\text { Trust in PHS program } \\
\text { based on the program } \\
\text { director } \\
\text { - Community distrusts the } \\
\text { water utility and local } \\
\text { government }\end{array}$ \\
\hline
\end{tabular}

In the case of Coatepec's FIDECOAGUA, the use of an interinstitutional committee to make key program decisions has allowed few institutional stakeholders to be aware of the program dynamics and influence in its decision making. Trust is built on having access, standing, and the ability to influence decision making $[13,21,34]$ and committee members who were interviewed trusted the program administrator and the local government. However, non-committee members such as local non-profit organizations, academia, landowners, water users, citizen groups, and farm associations distrusted the program administrator and the local government, as they did not have access to decision making except through one-way communication mechanisms (i.e., informing and consulting).

The case study about Xalapa's ANA program shows that there are high levels of trust between PHS stakeholders as different forms of engagement have been used to grant access, standing, and influence over PHS program decision making [14,17]. Community members, farm associations, enrolled landowners in PHS programs, and water users are encouraged to participate in the decision making and co-management of the watershed. The use of collaboration in this case study shows that the program administrator has been able to contribute to capacity building by empowering local communities to embrace collective decision making and co-management $[12,14,23]$.

In the case of Buga's PICB program, the top-down one-way communication and/or consultation approach to stakeholder participation has allowed the program administrator 
to build trust with community members and institutions. Similar to FIDECOAGUA, Aguas de Buga created a technical committee to make key decisions about the program and receive feedback from technical experts about hydrological processes, forest management, and land prioritization. The PICB committee was formed by several governmental agencies and local non-profit organizations and has been useful not only to make decisions about the program, but also to coordinate inter-institutional activities in the watershed. The committee does not have the participation of communities often marginalized from decision making, but it has not affected the credibility of the program by urban and rural citizens.

Our findings suggest that, in terms of trust and power sharing, outcomes of participation do not depend on the modes of engagement only, but on contextual factors as well (Figure 1) $[13,31,34]$. For instance, trust in the program is related to the role played by the water utility staff who administers the program (social factor), where the financial resource come from (economic factor), and limited influence of local politicians on the program (political factor). We also found that the design of the PHS program influences the perception of program trustworthiness [14,31]. The use of a transparent and clear operational scheme and non-cash, in-kind payments have contributed to foster trust in the program administration, especially when there are non-state actors involved in program auditing.

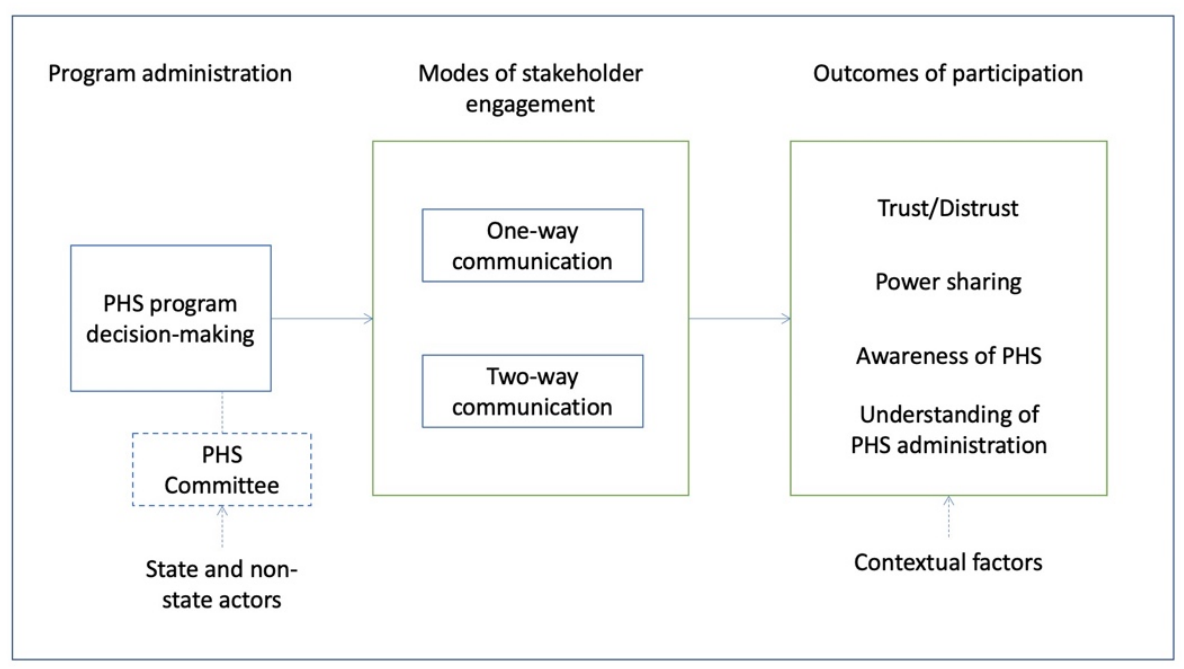

Figure 1. Influence of modes of stakeholder engagement and contextual factors on participation outcomes.

Trust in PHS programs, and program administrators, does not depend on the type of approach to stakeholder participation only, but on other factors such as legal constraints in eligibility criteria, administrative procedures and bureaucracy, political affiliation, existing relationships between community members and between them and institutional actors, and social conflicts such as the conflict in Colombia [31]. Our findings highlight that PHS program administrators, policy makers, PHS advocates, and governmental organizations must pay attention to address contextual factors, such as the existence of community networks, weak/strong community support and involvement, legal norms applied to PHS funding, support and/or involvement of the government, and social conflicts, that can produce and/or influence different outcomes of public engagement [31,102].

The importance of trust and power-sharing in PHS programs draws attention to the mainstream notion of PHS that embraces the neoliberal approach to conservation of biodiversity and ecosystem services $[1,2,5]$. PHS is a prominent market-based policy tool applied worldwide that focuses on providing financial incentives for conservation to counteract the effects of destructive land uses $[6,38]$. The PHS concept does not consider non-economic values that are relevant for local communities, such as fairness, care, justice, and shared responsibility [51,107]. We have argued that trust between key actors and institutions is an essential but underappreciated aspect of successful collaboration within 
PHS initiatives that needs to be considered and fostered by state and non-state actors to produce meaningful social and environmental outcomes.

The implications of the modes of public participation for trust, power, and public engagement in environmental decision making we have discussed in this paper may inform future research and practice on the role of stakeholders in PHS program's design, implementation, and monitoring globally. First, although PHS tends to be a mainstream environmental policy based on the marketization of nature [44-47], PHS designers and implementers need to consider the social, environmental, economic, and political complexity of local contexts $[31,37,53,102]$. Assuming that a generic approach to PHS would be effective and applicable to heterogenous contexts may increase distrust in governmental programs and environmental projects.

Second, many advocates of, and scholars in, public participation and environmental conflict management have supported the idea that facilitators must work on trust-building to foster better spaces for collaborative decision making and problem-solving $[12,14,15]$. However, some scholars have warned that researchers and facilitators need to acknowledge the coexistence of trust and distrust [21,34,108]. As Emborg et al. (2020) have argued, "in some situations management and mitigation of distrust may represent a more accurate depiction of the challenge natural resource managers face, while in other situations it may be effective to develop trust building strategies that specifically are designed to build calculus-based trust at the institutional level" [21] (p. 10).

Working towards building trust is often promoted in the literature in conflict management $[12,15,109]$, yet some authors have also suggested that understanding and managing distrust can potentially contribute to the design of environmental programs according to contextual factors [21]. We found that understanding the causes of distrust is important to begin fostering participation in PHS programs and environmental decision making. PHS program administrators and advocates need to conduct an assessment of the possible causes of distrust to build clear pathways to engaging the public in PHS programs $[15,109,110]$.

Emborg et al.'s (2020) warning might have implications and possibilities to promote PHS programs in communities that have been affected by intractable social conflicts, such as war $[109,110]$. In the case in Colombia, it is particularly relevant to consider the current post-peace agreement socio-political milieu to analyze the implications of the armed conflict on people's trust in governmental institutions and market-oriented programs for conservation $[81,82,111]$. Recent publications have called attention to increasing deforestation in national parks and rural areas previously controlled by far-left armed groups [74-77,111], which can impact both landowners' willingness to participate in a PHS program and/or the effectiveness of these programs to achieve social and environmental goals.

Given that the creation of PHS programs responds to institutional efforts to address deforestation and forest degradation globally $[6,38]$, in this paper, we analyzed the general perception of stakeholder participation in PHS programs from an institutional perspective. The methods described in this paper may allow to understand the organizational structure of PHS programs and uncover perceptions of key stakeholders on PHS program design, implementation, and monitoring in other case studies [68]. Research in environmental decision making often uses interviews of institutional actors to deepen the organizational structure of PHS programs and their strategies for public engagement [43].

However, there are some study limitations that we need to acknowledge. First, focusing interviews on institutional actors does not inform about what non-state actors often marginalized from decision making perceive about their participation in PHS program decision making. Future research could focus on the ways enrolled landowners, water users, and other citizen groups perceive trust in program decision making and how the agency and mode of engagement shape their perception of the program's trustworthiness $[15,21,34]$. Understanding how different PHS stakeholders perceive trust in program administrators and institutions can enrich the discussion of the implications of the modes of public participation for trust, power, and public engagement in PHS decision making. 
Second, using purposive and snowball sampling methods assisted with finding interviewees. However, the recruitment method required research members in the field to look for potential interviewees. Our data collection was interrupted by the COVID-19 pandemic in 2020 and we could not interview other PHS program stakeholders. Follow-up research in these case studies can expand the list of organizations and stakeholders to broaden perspectives on participation in PHS program decision making.

Third and last, this paper discusses how and to what extent diverse modes of stakeholder participation in PHS decision making can impact participation outcomes. Our research does not assume that better social and environmental outcomes develop from more participatory means. Future research can evaluate how different types of agency and modes of stakeholder engagement contribute to produce social and biophysical outcomes and what contextual factors have the potential to influence the effectiveness of PHS programs $[30,31,37,102]$.

Author Contributions: Conceptualization, A.M.U.-B., T.L.S. and P.H.; Formal analysis, A.M.U.-B.; Methodology, A.M.U.-B. and T.L.S.; Supervision, T.L.S.; Writing—original draft, A.M.U.-B.; Writingreview \& editing, A.M.U.-B., T.L.S., P.H. and C.M.A. All authors have read and agreed to the published version of the manuscript.

Funding: This work was funded partially by the USA's NSF Dynamics of Coupled Natural-Human Systems (CNH) program (grant No. 1313804), the University of New Hampshire's (UNH) Collaborative Research Excellence (CoRE) Initiative, the Randolph Pack Institute at SUNY College of Environmental Science and Forestry, and the Program for the Advancement of Research on Conflict and Collaboration (PARCC) at the Maxwell School of Syracuse University.

Institutional Review Board Statement: The study was conducted according to the guidelines of the Declaration of Helsinki, and approved by the Institutional Review Board (or Ethics Committee) of Syracuse University (protocol code 19-153 approved on June 20 of 2019) and University of New Hampshire (protocol code 7046 approved on October 25 of 2018).

Informed Consent Statement: Informed consent was obtained from all subjects involved in the study.

Data Availability Statement: Interview responses are not made publicly available to protect participant confidentiality, in compliance with the University of New Hampshire's Institutional Review Board (IRB) approval IRB \#7046 and Syracuse University's IRB approval \#19-153. Protocol available from the author upon request.

Acknowledgments: The authors would like to thank the interviewees from the cities of Xalapa and Coatepec (Mexico) and Guadalajara de Buga (Colombia) whose responses contributed to analyze the case studies.

Conflicts of Interest: The authors declare no conflict of interest.

\section{References}

1. Wunder, S. Revisiting the concept of payments for environmental services. Ecol. Econ. 2015, 117, 234-243. [CrossRef]

2. Wunder, S.; Brouwer, R.; Engel, S.; Ezzine-De-Blas, D.; Muradian, R.; Pascual, U.; Pinto, R. From principles to practice in paying for nature's services. Nat. Sustain. 2018, 1, 145-150. [CrossRef]

3. Engel, S.; Pagiola, S.; Wunder, S. Designing payments for environmental services in theory and practice: An overview of the issues. Ecol. Econ. 2008, 65, 663-674. [CrossRef]

4. Wunder, S. Payments for Environmental Services: Some Nuts and Bolts; Center for International Forestry Research (CIFOR) Occasional Paper No. 42; CIFOR: Bogor, Indonesia, 2005; pp. 1-25.

5. Muradian, R.; Corbera, E.; Pascual, U.; Kosoy, N.; May, P. Reconciling theory and practice: An alternative conceptual framework for understanding payments for environmental services. Ecol. Econ. 2010, 69, 1202-1208. [CrossRef]

6. Asbjornsen, H.; Mayer, A.S.; Jones, K.; Selfa, T.; Saenz, L.; Kolka, R.K.; Halvorsen, K.E. Assessing Impacts of Payments for Watershed Services on Sustainability in Coupled Human and Natural Systems. Bioscience 2015, 65, 579-591. [CrossRef]

7. Bremer, L.L.; Farley, K.A.; Lopez-Carr, D.; Romero, J. Conservation and livelihood outcomes of payment for ecosystem services in the Ecuadorian Andes: What is the potential for 'win-win'? Ecosyst. Serv. 2014, 8, 148-165. [CrossRef]

8. Von Thaden, J.J.; Manson, R.H.; Congalton, R.G.; López-Barrera, F.; Jones, K.W. Evaluating the environmental effectiveness of payments for hydrological services in Veracruz, México: A landscape approach. Land Use Policy 2021, 100, 105055. [CrossRef] 
9. Von Thaden, J.J.; Manson, R.H.; Congalton, R.G.; López-Barrera, F.; Salcone, J. A regional evaluation of the effectiveness of Mexico's payments for hydrological services. Reg. Environ. Change 2019, 19, 1751-1764. [CrossRef]

10. Jones, K.W.; Mayer, A.; Von Thaden, J.J.; Berry, Z.C.; López-Ramírez, S.; Salcone, J.; Manson, R.H.; Asbjornsen, H. Measuring the net benefits of payments for hydrological services programs in Mexico. Ecol. Econ. 2020, 175, 106666. [CrossRef]

11. Jones, K.W.; Foucat, S.A.; Pischke, E.C.; Salcone, J.; Torrez, D.; Selfa, T.; Halvorsen, K.E. Exploring the connections between participation in and benefits from payments for hydrological services programs in Veracruz State, Mexico. Ecosyst. Serv. 2019, 35, 32-42. [CrossRef]

12. Daniels, S.E.; Walker, G.B. Working through Environmental Conflict: The Collaborative Learning Approach; Praeger Publishers: Westport, CT, USA, 2001.

13. Walker, G.B.; Senecah, S.L.; Daniels, S.E. From the forest to the river: Citizens' views of stakeholder engagement. Hum. Ecol. Rev. 2006, 13, 193-202.

14. Walker, G.B.; Daniels, S.E. Collaboration in Environmental Conflict Management and Decision-Making: Comparing Best Practices with Insights from Collaborative Learning Work. Front. Commun. 2019, 4, 1-12. [CrossRef]

15. Clarke, T.; Peterson, T.R. Environmental Conflict Management, 1st ed.; SAGE Publications: Thousand Oaks, CA, USA, 2016.

16. Peterson, T.R.; Stephens, J.C.; Wilson, E.J. Public perception of and engagement with emerging low-carbon energy technologies: A literature review. MRS Energy Sustain. 2015, 2, 1-14. [CrossRef]

17. Banerjee, P.; Wang, H.-H.; Peterson, M.; Grant, W.E.; Peterson, T.R. Collaborative Modeling and Social Learning in the Context of Joint Forest Management in East Sikkim, India. Front. Environ. Sci. 2019, 7, 1-16. [CrossRef]

18. Walker, G.B. Public Participation as Participatory Communication in Environmental Policy Decision-Making: From Concepts to Structured Conversations. Environ. Commun. 2007, 1, 99-110. [CrossRef]

19. Fujitani, M.; McFall, A.; Randler, C.; Arlinghaus, R. Participatory adaptive management leads to environmental learning outcomes extending beyond the sphere of science. Sci. Adv. 2017, 3, e1602516. [CrossRef] [PubMed]

20. Daniels, S.E.; Walker, G.B. Collaborative learning: Improving public deliberation in ecosystem-based management. Environ. Impact Assess. Rev. 1996, 16, 71-102. [CrossRef]

21. Emborg, J.; Daniels, S.E.; Walker, G.B. A Framework for Exploring Trust and Distrust in Natural Resource Management. Front. Commun. 2020, 5, 13. [CrossRef]

22. Wedemeyer-Strombel, K.R.; Peterson, M.J.; Sanchez, R.N.; Chavarría, S.; Valle, M.; Altamirano, E.; Gadea, V.; Sowards, S.K.; Tweedie, C.E.; Liles, M.J. Engaging Fishers' Ecological Knowledge for Endangered Species Conservation: Four Advantages to Emphasizing Voice in Participatory Action Research. Front. Commun. 2019, 4, 1-13. [CrossRef]

23. Norton, B.G. Sustainable Values, Sustainable Change; The University of Chicago Press: Chicago, IL, USA, 2015.

24. Ostrom, E. Governing the Commons: The Evolution of Institutions for Collective Action; Cambridge University Press: Cambridge, UK, 1990.

25. Arnstein, S.R. A Ladder of Citizen Participation. J. Am. Inst. Plan. 1969, 35, 216-224. [CrossRef]

26. Thompson, J.L.; Forster, C.B.; Werner, C.; Peterson, T.R. Mediated Modeling: Using Collaborative Processes to Integrate Scientist and Stakeholder Knowledge about Greenhouse Gas Emissions in an Urban Ecosystem. Soc. Nat. Resour. 2010, 23, 742-757. [CrossRef]

27. Hall, D.M.; Gilbertz, S.J.; Anderson, M.B.; Ward, L.C. Beyond "buy-in": Designing citizen participation in water planning as research. J. Clean. Prod. 2016, 133, 725-734. [CrossRef]

28. Chari, R.; Blumenthal, M.; Matthews, L. Community Citizen Science: From Promise to Action; RAND Corporation: Santa Monica, CA, USA, 2019.

29. Lumosi, C.K.; Pahl-Wostl, C.; Scholz, G. Can 'learning spaces' shape transboundary management processes? Evaluating emergent social learning processes in the Zambezi basin. Environ. Sci. Policy 2019, 97, 67-77. [CrossRef]

30. Reed, M.S. Stakeholder participation for environmental management: A literature review. Biol. Conserv. 2008, 141, $2417-2431$. [CrossRef]

31. Reed, M.S.; Vella, S.; Challies, E.; De Vente, J.; Frewer, L.; Hohenwallner-Ries, D.; Huber, T.; Neumann, R.K.; Oughton, E.A.; Del Ceno, J.S.; et al. A theory of participation: What makes stakeholder and public engagement in environmental management work? Restor. Ecol. 2018, 26, S7-S17. [CrossRef]

32. McFadgen, B.; Huitema, D. Stimulating Learning through Policy Experimentation: A Multi-Case Analysis of How Design Influences Policy Learning Outcomes in Experiments for Climate Adaptation. Water 2017, 9, 648. [CrossRef]

33. Moreau, C.; Barnaud, C.; Mathevet, R. Conciliate Agriculture with Landscape and Biodiversity Conservation: A Role-Playing Game to Explore Trade-Offs among Ecosystem Services through Social Learning. Sustainability 2019, 11, 310. [CrossRef]

34. Senecah, S.L. Chapter 1: The Trinity of Voice: The role of practical theory in planning and evaluating the effectiveness of environmental participatory processes. In Communication and Public Participation in Environmental Decision Making, 1st ed.; Depoe, S., Delicath, J., Elsenbeer, M.-F.A., Eds.; State University of New York Press: Albany, NY, USA, 2004; pp. 13-33.

35. Grima, N.; Singh, S.; Smetschka, B.; Ringhofer, L. Payment for Ecosystem Services (PES) in Latin America: Analysing the performance of 40 case studies. Ecosyst. Serv. 2016, 17, 24-32. [CrossRef] 
36. Bailey, K.; Grossardt, T. Addressing the Arnstein Gap: Improving Public Confidence in Transportation Planning and Design through Structured Public Involvement (SPI); Kentucky Transportation Center Faculty and Researcher Publications: Lexington, KY, USA, 2006. pp. 337-341. Available online: http://uknowledge.uky.edu/ktc_facpub\%5Cnhttp://uknowledge.uky.edu/ktc_facpub/3 (accessed on 13 December 2020).

37. Sprain, L.; Tompsett, C.; Ertor, P.; Asara, V. The 'Wickedness' of Participation in Climate Change Adaptation Governance; Institutions for Sustainable Development; Norwegian University of Life Sciences: As, Norway, 2011; Volume 1, pp. 77-93.

38. Asbjornsen, H.; Manson, R.H.; Scullion, J.J.; Holwerda, F.; Muñoz-Villers, L.E.; Alvarado-Barrientos, M.S.; Geissert, D.; Dawson, T.E.; McDonnell, J.J.; Bruijnzeel, L.A. Interactions between payments for hydrologic services, landowner decisions, and ecohydrological consequences: Synergies and disconnection in the cloud forest zone of central Veracruz, Mexico. Ecol. Soc. 2017, $22,25-42$. [CrossRef]

39. Hayes, T.; Grillos, T.; Bremer, L.L.; Murtinho, F.; Shapiro, E. Collective PES: More than the sum of individual incentives. Environ. Sci. Policy 2019, 102, 1-8. [CrossRef]

40. Ingram, J.C.; Wilkie, D.; Clements, T.; McNab, R.B.; Nelson, F.; Baur, E.H.; Sachedina, H.T.; Peterson, D.D.; Foley, C.A.H. Evidence of Payments for Ecosystem Services as a mechanism for supporting biodiversity conservation and rural livelihoods. Ecosyst. Serv. 2014, 7, 10-21. [CrossRef]

41. Pfaff, A.; Rodriguez, L.A.; Shapiro-Garza, E. Collective Local Payments for ecosystem services: New local PES between groups, sanctions, and prior watershed trust in Mexico. Water Resour. Econ. 2019, 28, 100136. [CrossRef]

42. Rawlins, M.A.; Westby, L. Community participation in payment for ecosystem services design and implementation: An example from Trinidad. Ecosyst. Serv. 2013, 6, 117-121. [CrossRef]

43. Salzman, J.; Bennett, G.; Carroll, N.; Goldstein, A.; Jenkins, M. The global status and trends of Payments for Ecosystem Services. Nat. Sustain. 2018, 1, 136-144. [CrossRef]

44. McAfee, K. Green economy and carbon markets for conservation and development: A critical view. Int. Environ. Agreem. Politics Law Econ. 2016, 16, 333-353. [CrossRef]

45. McAfee, K. Nature in the Market-World: Ecosystem services and inequality. Development 2012, 55, 25-33. [CrossRef]

46. Fletcher, R.; Büscher, B. The PES Conceit: Revisiting the Relationship between Payments for Environmental Services and Neoliberal Conservation. Ecol. Econ. 2017, 132, 224-231. [CrossRef]

47. Fletcher, R.; Büscher, B. Neoliberalism in Denial in Actor-oriented PES Research? A Rejoinder to Van Hecken et al. (2018) and a Call for Justice. Ecol. Econ. 2019, 156, 420-423. [CrossRef]

48. Braasch, M.; García-Barrios, L.; Cortina-Villar, S.; Huber-Sannwald, E.; Ramírez-Marcial, N. TRUE GRASP: Actors visualize and explore hidden limitations of an apparent win-win land management strategy in a MAB reserve. Environ. Model. Softw. 2018, 105, 153-170. [CrossRef]

49. Grillos, T. Economic vs non-material incentives for participation in an in-kind payments for ecosystem services program in Bolivia. Ecol. Econ. 2017, 131, 178-190. [CrossRef]

50. He, J. Situated Payments for Ecosystem Services: Local Agencies in the Implementation of the Sloping Land Conversion Programme in Southwest China. Dev. Chang. 2020, 51, 73-93. [CrossRef]

51. Irvine, K.N.; O’Brien, L.; Ravenscroft, N.; Cooper, N.; Everard, M.; Fazey, I.; Reed, M.S.; Kenter, J. Ecosystem services and the idea of shared values. Ecosyst. Serv. 2016, 21, 184-193. [CrossRef]

52. Sims, K.R.E.; Alix-Garcia, J.M.; Shapiro-Garza, E.; Fine, L.R.; Radeloff, V.C.; Aronson, G.; Castillo, S.; Ramirez-Reyes, C.; YañezPagans, P. Improving Environmental and Social Targeting through Adaptive Management in Mexico's Payments for Hydrological Services Program. Conserv. Biol. 2014, 28, 1151-1159. [CrossRef] [PubMed]

53. Shapiro-Garza, E.; McElwee, P.; Van Hecken, G.; Corbera, E. Beyond Market Logics: Payments for Ecosystem Services as Alternative Development Practices in the Global South. Dev. Chang. 2020, 51, 3-25. [CrossRef]

54. Shapiro-Garza, E. An Alternative Theorization of Payments for Ecosystem Services from Mexico: Origins and Influence. Dev. Chang. 2020, 51, 196-223. [CrossRef]

55. Van Hecken, G.; Kolinjivadi, V.; Windey, C.; McElwee, P.; Shapiro-Garza, E.; Huybrechs, F.; Bastiaensen, J. Silencing Agency in Payments for Ecosystem Services (PES) by Essentializing a Neoliberal 'Monster' Into Being: A Response to Fletcher \& Büscher's 'PES Conceit'. Ecol. Econ. 2018, 144, 314-318. [CrossRef]

56. Setyowati, A.B. Making Territory and Negotiating Citizenship in a Climate Mitigation Initiative in Indonesia. Dev. Chang. 2020, 51, 144-166. [CrossRef]

57. Upton, C. Conserving Natures? Co-producing Payments for Ecosystem Services in Mongolian Rangelands. Dev. Chang. 2020, 51, 224-252. [CrossRef]

58. McElwee, P.; Huber, B.; Nguyễn, T.H.V. Hybrid Outcomes of Payments for Ecosystem Services Policies in Vietnam: Between Theory and Practice. Dev. Chang. 2020, 51, 253-280. [CrossRef]

59. Nelson, S.H.; Bremer, L.L.; Prado, K.M.; Brauman, K.A. The Political Life of Natural Infrastructure: Water Funds and Alternative Histories of Payments for Ecosystem Services in Valle del Cauca, Colombia. Dev. Chang. 2020, 51, 26-50. [CrossRef]

60. Ragin, C.C.; Becker, H.S. What is a Case?: Exploring the Foundations of Social Inquiry; Cambridge University Press: Cambridge, UK, 1992.

61. Yin, R.K. Case Study Research and Applications: Design and Methods, 6th ed.; SAGE Publications: Los Angeles, CA, USA, 2017. 
62. Alix-Garcia, J.; De Janvry, A.; Sadoulet, E.; Manuel, J. Lessons Learned from Mexico's Payment for Environmental Services Program. In Payment for Environmental Services in Agricultural Landscapes; Springer: New York, NY, USA, 2009 ; pp. 163-188.

63. CONANP. Pago Por Servicios Ambientales en Áreas Naturales Protegidas; CONANP: Mexico City, Mexico, 2010.

64. Muñoz-Piña, C.; Guevara, A.; Torres, J.M.; Braña, J. Paying for the hydrological services of Mexico's forests: Analysis, negotiations and results. Ecol. Econ. 2008, 65, 725-736. [CrossRef]

65. Muñoz-Piña, C.; Rivera, M.; Cisneros, A.; García, H. Retos de la focalización del Programa de Pago por los Servicios Ambientales en México. Rev. Esp. Estud. Agrosoc. Pesq. 2011, 228, 87-113.

66. Jones, K.W.; Powlen, K.; Roberts, R.; Shinbrot, X. Participation in payments for ecosystem services programs in the Global South: A systematic review. Ecosyst. Serv. 2020, 45, 101159. [CrossRef]

67. López-Ramírez, S.M.; Sáenz, L.; Mayer, A.; Muñoz-Villers, L.E.; Asbjornsen, H.; Berry, Z.C.; Looker, N.; Manson, R.; GómezAguilar, L.R. Land use change effects on catchment streamflow response in a humid tropical montane cloud forest region, central Veracruz, Mexico. Hydrol. Process. 2020, 34, 3555-3570. [CrossRef]

68. Nava-López, M.; Selfa, T.L.; Cordoba, D.; Pischke, E.C.; Torrez, D.; Ávila-Foucat, S.; Halvorsen, K.E.; Maganda, C. Decentralizing Payments for Hydrological Services Programs in Veracruz, Mexico: Challenges and Implications for Long-term Sustainability. Soc. Nat. Resour. 2018, 31, 1389-1399. [CrossRef]

69. Rodriguez, K.; Ávila-Foucat, S. Instrumentos económicos voluntarios para la conservación: Una mirada a su surgimiento y evolución en México. Soc. Econ. 2013, 25, 75-106.

70. Gómez-Díaz, J.A.; Brast, K.; Degener, J.; Krömer, T.; Ellis, E.; Heitkamp, F.; Gerold, G. Long-Term Changes in Forest Cover in Central Veracruz, Mexico (1993-2014). Trop. Conserv. Sci. 2018, 11, 1-12. [CrossRef]

71. Bonilla-Moheno, M.; Aide, T.M. Beyond deforestation: Land cover transitions in Mexico. Agric. Syst. 2020, 178, 102734. [CrossRef]

72. Kosoy, N.; Corbera, E.; Brown, K. Participation in payments for ecosystem services: Case studies from the Lacandon rainforest, Mexico. Geoforum 2008, 39, 2073-2083. [CrossRef]

73. Paré, L.; Fuentes, T. El comité de cuenca del río Pixquiac: Alternativas para la cogestión de una cuenca abastecedora. In Gestión Para la Defensa del Agua y el Territorio en Xalapa Veracruz, 1st ed.; Paré, L., García-Campos, H., Eds.; Universidad Nacional Autónoma de México: Mexico City, Mexico, 2018; p. 212.

74. Clerici, N.; Armenteras, D.; Kareiva, P.; Botero, R.; Ramírez-Delgado, J.P.; Forero-Medina, G.; Ochoa, J.; Pedraza, C.; Schneider, L.; Lora, C.; et al. Deforestation in Colombian protected areas increased during post-conflict periods. Sci. Rep. 2020, $10,4971$. [CrossRef]

75. Negret, P.J.; Sonter, L.; Watson, J.E.M.; Possingham, H.P.; Jones, K.R.; Suarez, C.; Ochoa-Quintero, J.M.; Maron, M. Emerging evidence that armed conflict and coca cultivation influence deforestation patterns. Biol. Conserv. 2019, 239, 108176. [CrossRef]

76. Prem, M.; Saavedra, S.; Vargas, J.F. End-of-conflict deforestation: Evidence from Colombia's peace agreement. World Dev. 2020, 129, 104852. [CrossRef]

77. Sanchez-Cuervo, A.M.; Aide, T.M. Identifying hotspots of deforestation and reforestation in Colombia (2001-2010): Implications for protected areas. Ecosphere 2013, 4, art143. [CrossRef]

78. Becerra, M.R. Nuestro Planeta, Nuestro Futuro, 1st ed.; Penguin Random House Grupo Editorial, S.A.S.: Bogota, Colombia, 2019.

79. Castro-Nunez, A.; Charry, A.; Castro-Llanos, F.; Sylvester, J.; Bax, V. Reducing deforestation through value chain interventions in countries emerging from conflict: The case of the Colombian cocoa sector. Appl. Geogr. 2020, 123, 102280. [CrossRef]

80. Seymour, F.; Harris, N.L. Reducing tropical deforestation. Science 2019, 365, 756-757. [CrossRef]

81. Martínez, A.Á. Detrás de la Guerra en Colombia, 2nd ed.; Editorial Planeta Colombia S.A.: Bogota, Colombia, 2019.

82. Furumo, P.R.; Lambin, E.F. Scaling up zero-deforestation initiatives through public-private partnerships: A look inside postconflict Colombia. Glob. Environ. Chang. 2020, 62, 102055. [CrossRef]

83. Ministerio de Ambiente y Desarrollo Sostenible; Departamento Nacional de Planeación. Pagos por Servicios Ambientales Versión 2.0. 2018; pp. 2-25. Available online: https://proyectostipo.dnp.gov.co/images/pdf/PSA-NOV2018.pdf (accessed on 25 January 2021).

84. Calvache, A.; Benítez, S.; Ramos, A. WATER FUNDS Conserving Green Infrastructure: A Guide for Design, Creation and Operation; The Nature Conservancy: Bogota, Colombia, 2012.

85. Fondo Patrimonio Natural; CIPAV; CVC; DAGMA; PNN Farallones de Cali; EMCALI. Compensación por Servicios Ambientales Hídricos en la Cuenca del río Cali-Valle del Cauca; Fondo Patrimonio Natural: Bogota, Colombia, 2014.

86. Rodríguez-Dowdell, N.; Yépez-Zabala, Í; Green, K.; Calderón-Villela, E. Pride for ARAs: A Guide to Reciprocal Water Agreements for People and Nature, 1st ed.; Rare: Arlington, VA, USA, 2014.

87. Schneider, A. Reciprocal Water Agreements, a New Approach on Watershed-Conservation? Öffentliche Sektor 2018, 44, 69-78.

88. Bétrisey, F.; Bastiaensen, J.; Mager, C. Payments for ecosystem services and social justice: Using recognition theories to assess the Bolivian Acuerdos Recíprocos por el Agua. Geoforum 2018, 92, 134-143. [CrossRef]

89. Martinez, R.; Green, K.M.; DeWan, A. Establishing reciprocal agreements for water and biodiversity conservation through a social marketing campaign in Quanda watershed, Peru. Conserv. Evid. 2013, 10, $42-47$.

90. Kovács, E.; Kumar, C.; Agarwal, C.; Adams, W.; Hope, R.; Vira, B. The politics of negotiation and implementation: A reciprocal water access agreement in the Himalayan foothills, India. Ecol. Soc. 2016, 21, 37. [CrossRef]

91. Paré, L.; Campos, H.G. Gestión para la Defensa del Agua y el Territorio en Xalapa, Veracruz, 1st ed.; Universidad Nacional Autónoma de México: Mexico City, Mexico, 2018. 
92. Creswell, J.W.; Poth, C. Qualitative Inquiry and Research Design, 4th ed.; SAGE Publications: Los Angeles, CA, USA, 2018.

93. Depoe, S.; Delicath, J.; Elsenbeer, M.-F.A. Communication and Public Participation in Environmental Decision Making; State University of New York Press: Albany, NY, USA, 2004.

94. Brummel, R.F.; Nelson, K.C.; Souter, S.G.; Jakes, P.J.; Williams, D.R. Social learning in a policy-mandated collaboration: Community wildfire protection planning in the eastern United States. J. Environ. Plan. Manag. 2010, 53, 681-699. [CrossRef]

95. DeFries, R.; Nagendra, H. Ecosystem management as a wicked problem. Science 2017, 356, 265-270. [CrossRef]

96. Tsegaye, G.; Dondeyne, S.; Lemenih, M.; Marye, A.; Nyssen, J.; Deckers, J.A.; Maertens, M. 'Facing conservation' or 'conservation with a human face'? People-Park interactions in southern Ethiopia. J. East. Afr. Stud. 2017, 11, 290-309. [CrossRef]

97. Pahl-Wostl, C. A conceptual framework for analysing adaptive capacity and multi-level learning processes in resource governance regimes. Glob. Environ. Chang. 2009, 19, 354-365. [CrossRef]

98. Euler, J.; Heldt, S. From information to participation and self-organization: Visions for European river basin management. Sci. Total. Environ. 2018, 621, 905-914. [CrossRef] [PubMed]

99. Roldán, A.M.; Duit, A.; Schultz, L. Does stakeholder participation increase the legitimacy of nature reserves in local communities? Evidence from 92 Biosphere Reserves in 36 countries. J. Environ. Policy Plan. 2019, 21, 188-203. [CrossRef]

100. Halvorsen, K.E. Critical Next Steps in Research on Public Meetings and Environmental Decision Making. Hum. Ecol. Rev. 2006, $13,150-160$.

101. Hopkins, D. The emancipatory limits of participation in planning: Equity and power in deliberative plan-making in Perth, Western Australia. Town Plan. Rev. 2010, 81, 55-81. [CrossRef]

102. Sprain, L. Paradoxes of Public Participation in Climate Change Governance. Good Soc. 2016, 25, 62-80. [CrossRef]

103. Wondirad, A.; Ewnetu, B. Community participation in tourism development as a tool to foster sustainable land and resource use practices in a national park milieu. Land Use Policy 2019, 88, 104155. [CrossRef]

104. Lliso, B.; Pascual, U.; Engel, S.; Mariel, P. Payments for ecosystem services or collective stewardship of Mother Earth? Applying deliberative valuation in an indigenous community in Colombia. Ecol. Econ. 2020, 169, 106499. [CrossRef]

105. Hayes, T.; Murtinho, F.; Wolff, H. An institutional analysis of Payment for Environmental Services on collectively managed lands in Ecuador. Ecol. Econ. 2015, 118, 81-89. [CrossRef]

106. Swapan, M.S.H. Who participates and who doesn't? Adapting community participation model for developing countries. Cities 2016, 53, 70-77. [CrossRef]

107. Kenter, J.O.; O’Brien, L.; Hockley, N.; Ravenscroft, N.; Fazey, I.; Irvine, K.N.; Reed, M.S.; Christie, M.; Brady, E.; Bryce, R.; et al. What are shared and social values of ecosystems? Ecol. Econ. 2015, 111, 86-99. [CrossRef]

108. Weymouth, R.; Hartz-Karp, J. Participation in planning and governance: Closing the gap between satisfaction and expectation. Sustain. Earth 2019, 2, 5. [CrossRef]

109. Kriesberg, L.; Dayton, B.W. Constructive Conflicts: From Escalation to Resolution, 5th ed.; Rowman \& Littlefield: London, UK, 2017.

110. Elman, M.F.; Gerard, C.; Golan, G.; Kriesberg, L. (Eds.) Overcoming Intractable Conflicts: New Approaches to Constructive Transformations; Rowman \& Littlefield: London, UK, 2019.

111. Liévano-Latorre, L.F.; Brum, F.T.; Loyola, R. How effective have been guerrilla occupation and protected areas in avoiding deforestation in Colombia? Biol. Conserv. 2021, 253, 108916. [CrossRef] 